Sains Malaysiana 51(1)(2022): 67-81

http://doi.org/10.17576/jsm-2022-5101-06

\title{
Comparison between Satellite-Derived Rainfall and Rain Gauge Observation over Peninsular Malaysia
}

(Perbandingan antara Pemerhatian Hujan Satelit Terbitan dan Tolok Hujan di Semenanjung Malaysia)

\author{
Ahmad Fairudz JamaluddiN*, Muhammad Ikmalnor Mustafa Kamal, Muhammad Helmi Abdullah \& \\ AMIRUL NIZAM MARODZI
}

\begin{abstract}
Validation of the bias-corrected product of National Oceanic and Atmospheric Administration (NOAA) Climate Prediction Centre Morphing Technique CMORPH-CRT was conducted using gridded rain gauge dataset of Wong et al. (2011) and rain gauge data from meteorological stations throughout Peninsular Malaysia. The CMORPH-CRT was compared for four contrasting topographic sub-regions of Peninsular Malaysia, i.e. west coast (WC), foothills of Titiwangsa range (FT), inland-valley (IN) and east coast (EC). CMORPH-CRT product with grid resolution of $8 \mathrm{~km} \times 8 \mathrm{~km}$ at temporal resolution of 1-hour from 00Z January 1998 to $23 Z$ December 2018 was utilized. The results show that CMORPH-CRT are in agreement with the rain gauge data. The CMORPH-CRT performed best over coastal sub-regions but it underestimated over FT sub-region and overestimated at IN. CMORPH-CRT tend to perform better in moderate rather than heavy rainfall events. For extreme weather events, the CMORPH-CRT had shown capability in observing the formation and decay of low-pressure system in Penang during 4th November 2017 and it is in agreement with rain gauge based SPI index i.e. drought conditions over Peninsular Malaysia.
\end{abstract}

Keywords: Extreme flood; satellite rainfall; standardized precipitation index

ABSTRAK

Pengesahan pencerapan yang diperbetulkan secara pincang dari National Oceanic and Atmospheric Administration (NOAA) Climate Prediction Centre Morphing Technique (CMORPH-CRT) dilakukan dengan menggunakan rangkaian tolok hujan bergrid dari Wong et al. (2011) dan pencerapan tolok hujan daripada stesen meteorologi di seluruh Semenanjung Malaysia. Data CMORPH-CRT dibandingkan terhadap empat sub-rantauan topografi Semenanjung Malaysia yang berbeza, iaitu sub-rantauan pantai barat (WC), kaki bukit Banjaran Titiwangsa (FT), lembah-pedalaman (IN) dan pantai timur (EC). Resolusi grid $8 \mathrm{~km} \times 8 \mathrm{~km}$ dan resolusi temporal setiap jam CMORPH-CRT dari 00Z Januari 1998 hingga $23 Z$ Disember 2018 digunakan dalam kajian. Hasil kajian menunjukkan bahawa pencerapan CMORPH-CRT adalah tekal dengan pencerapan tolok hujan. CMORPH-CRT cenderung mencerap lebih baik di sub-rantauan pesisir pantai manakala berkurangan di kawasan pergunungan dan berlebihan di sub-rantauan lembah pedalaman. CMORPH-CRT juga cenderung mencerap lebih baik kejadian hujan sederhana berbanding hujan lebat. Untuk kejadian cuaca yang melampau, CMORPH-CRT menunjukkan keupayaan dalam mencerap pembentukan dan penguraian sistem bertekanan udara rendah di Pulau Pinang pada 4 November 2017 dan tekal dengan indeks SPI tolok hujan, yang seterusnya tekal dengan keadaan kemarau di Semenanjung Malaysia.

Kata kunci: Banjir besar; hujan satelit; indeks hujan piawai

\section{INTRODUCTION}

The climate of Peninsular Malaysia is strongly influenced by the Asian-Australian monsoon. Strong northeasterly winds dominate this region during December to February (DJF; known as the northeast monsoon), while during
June to August (JJA), southwesterly winds prevail over the region (known as the southwest monsoon). The period in between the two monsoon seasons is locally known as the inter-monsoon period. During the southwest monsoon, climate over the Peninsular Malaysia is 
generally drier (Jamaluddin et al. 2019, 2017). This drier climate is mainly due to the blockage effect caused by the Pergunungan Barisan over the Sumatra Island in Indonesia which prevents southwesterly winds from transporting moisture from the Indian Ocean to Peninsular Malaysia. Drought will often occur if this dry season is intensified and prolonged. On the other hand, during the northeast monsoon, widespread floods induced by heavy rain are common over the eastern coast of Peninsular Malaysia (Chang et al. 2005; Tangang et al. 2017, 2008). The existence of quasi-stationary vortex normally known as Borneo vortex that is embedded to monsoon trough modulates northeasterly wind to converge over the eastern coast of Peninsular Malaysia. Occasionally, the trough is intensified, causing the vortex to penetrate further north, reaching the northern Peninsular Malaysia and even southern Thailand (Lim 1979; Yik et al. 2018). This had resulted in flooding in the state of Penang and Kedah (both states are located over the northwest of Peninsular Malaysia) on $4^{\text {th }}$ November 2017 (Yik et al. 2018).

It is of high importance to obtain near real-time and accurate measurements of rainfall for early warning of flood and drought (Buurman et al. 2014). As part of the early warning of flood event, Malaysian Meteorological Department (MET Malaysia) issues severe weather warnings along with associated the danger level when continuous heavy rain is expected with rainfall exceeding $150 \mathrm{~mm}$ in $24 \mathrm{~h}$ (https://www.met.gov.my/ cuaca/kriteriaamaran hujanlebat?lang=en). On the other hand, drought usually requires a minimum of one to three months to become established but it can continue for months or years. Therefore, accurate measurements of rainfall appears to be more important than near realtime measurements for drought monitoring (e.g. Tan et al. 2017; Zin et al. 2013). Starting from the year 2000, a total of 221 automatic weather stations (AWS) have been installed to ensure near real-time rainfall data streaming over Peninsular Malaysia. However, the location of stations is quite sparse, thus it is insufficient for describing overall heavy rainfall conditions and related weather pattern over the whole of Peninsular Malaysia. Only a few meteorological stations are available in remote areas and those that are present are not well distributed, due to difficulties in accessing the areas for installation and maintenance (https://www.met.gov.my/pendidikan/ cuaca/peralatanmeteorologi).

In contrast with rain gauge observation, rainfall estimates derived from global space-based observations can better supply user needs by providing uniform and dense spatial coverage of rainfall information (Semire et al. 2012). In conjunction with providing uniform and dense spatial coverage of rainfall information, Climate
Prediction Center morphing technique (CMORPH) by National Oceanic and Atmospheric Administration (NOAA) and Global Satellite Mapping of Precipitation (GSMaP) by Japan Aerospace Exploration Agency (JAXA) offers near real-time measurements with a latency of 2 and $4 \mathrm{~h}$, respectively (http://sharaku.eorc.jaxa.jp/GSMaP/). In contrast to CMORPH and GSMaP, most other satellitederived rainfall products are not suitable for weather extreme monitoring especially for flood early warning over Peninsular Malaysia due to late data updates, unavailability of hourly data and coarse spatial resolution. An example of such data is the Climate Hazards Group Infrared Precipitation with Stations (CHIRPS) (Funk et al. 2015) which offers a minimum temporal scale of daily with 3 to 5 days for data to be updated. Other examples are the Tropical Rainfall Measuring Mission (TRMM) and the Precipitation Estimation from Remotely Sensed Information using Artificial Neural Networks (PERSIANN). The temporal resolution of TRMM 3B42 is 3-hourly, spatial resolution of $0.25^{\circ} \times 0.25^{\circ}$ and latency time of 7 h (Huffman \& Bolvin 2015; Wu et al. 2014). For PERSIANN, the temporal resolution is daily, spatial resolution of $0.25^{\circ} \times 0.25^{\circ}$ and updating time once in three months (Ashouri et al. 2015). A high resolution data with 0.05 degree is needed to assess rainfall variability in Peninsular Malaysia due to its relatively small area and complexity of the terrain (e.g. Ayoub et al. 2020; Jamaluddin et al. 2017; Wong et al. 2016). Taking these into consideration, this study opted for CMORPH rather than other available satellite-derived rainfall.

The CMORPH global high-resolution satellite rainfall has been reprocessed and bias corrected to $8 \mathrm{~km}$ $\times 8 \mathrm{~km}$ grid over the globe $\left(60^{\circ} \mathrm{S}-60^{\circ} \mathrm{N}\right)$ from January 1998 (Xie et al. 2017) to the present. The CMORPH are reprocessed using a fixed version of the integration algorithm as described by Joyce et al. (2004) and with input from Level 2 passive microwave (PMW) retrievals that are generated using the Goddard Profiling (GPROF) version 2004 algorithms (Kummerow et al. 2001). Bias correction is then performed for the reprocessed CMORPH through probability density function (PDF) matching against the Climate Prediction Centre (CPC) daily gauge analysis over land and through adjustment against the Global Precipitation Climatology Program (GPCP) pentad merged analysis of rainfall over ocean. An intercomparison study showed that the reprocessed and bias corrected CMORPH exhibits superior performance than the widely used Tropical Rainfall Measurement Mission (TRMM) 3B42 in representing both daily and 3-hourly rainfall over the United States and other global regions (Xie et al. 2017). 
A number of studies have evaluated satellite-derived rainfall for areas of interest by comparing it to rain gauge data (Fatkhuroyan et al. 2018; Setiawati \& Miura 2016). World Meteorological Organization's (WMO) new initiative - the Space-based Weather and Climate Extremes Monitoring (SWCEM) is established to assist Regional Climate Centers and National Meteorological and Hydrological Services with the delivery of reliable drought and heavy rainfall predictions. As a member of SWCEM, MET Malaysia contributes to the validation of the satellite-derived rainfall over the Peninsular Malaysia. For these purposes, we evaluate CMORPH with the rain-gauge data over different topography in Peninsular Malaysia. Case studies of (i) heavy rainfall over northwest of Peninsular Malaysia on $4^{\text {th }}$ November 2017; and (ii) drought in Peninsular Malaysia during February and March 2014 are also presented in the study. As the national authority on providing severe weather warnings in Malaysia, reliable and near real-time rainfall from CMORPH can provide useful information about current rainfall conditions and as a baseline for heavy rainfall predictions a few hours ahead. Secondly, having reliable CMORPH will allow the use of high-resolution gridded data compared to the current limited data points for drought monitoring over the Peninsular Malaysia. Currently, only 24 data points are used to calculate Standardized Precipitation Index (SPI) over the Peninsular Malaysia (https://www.met.gov.my/iklim/kemarau/ pemantauankemarau).

\section{DATA AND METHOD}

\section{CMORPH-CRT}

The original CMORPH version is called version $0 . x$, and the reprocessed CMORPH version is called version 1.0. The version 1.0 products contain three different rainfall products, i.e.: (i) raw (CMORPH-RAW); (ii) a bias-corrected product (CMORPH-CRT); and (iii) a gauge-satellite blended product (CMORPH-BLD). The CMORPH-RAW product is a satellite-only rainfall product that integrates passive microwave data from multiple low orbit satellites and the infrared data from multiple geostationary satellites to provide rainfall estimates with the spatial-temporal 8 km-hourly resolution (Duan et al. 2016). PDF matching, which performs a bias reduction function, is applied to CMORPH-RAW to generate the CMORPH-CRT product. This CMORPH-CRT product is available with $8 \mathrm{~km}$-hourly resolutions but with a latency of $2 \mathrm{~h}$. CMORPH-CRT precipitation estimates are then further calibrated via a gauge analysis using an optional interpolation technique to generate the CMORPH-BLD product (Wei et al. 2018). However, the CMORPH-BLD product is available only at the $0.25^{\circ}$ daily resolution with a latency of 2 days. Here, the spatial-temporal of $8 \mathrm{~km}$-hourly resolution of CMORPH-CRT products from 00Z January 1998 to $23 Z$ December 2018 was utilized. The CMORPH-CRT products of this study is downloaded from the official website at https://ftp.cpc.ncep.noaa.gov/precip/PORT/SEMDP/ CMORPH_CRT/DATA.

\section{RAIN GAUGE DATA}

The CMORPH-CRT capability in simulating seasonal mean of rainfall was evaluated based on $0.05^{\circ}$ resolution gridded daily rain gauge from Wong et al. (2011). This gridded daily rain gauge of Wong et al. (2011) which spans from 1976 to 2006 was derived from the daily rain gauge rainfall observation network, and consists of 123 stations that is spread across the Peninsular Malaysia (Mohd et al. 2015; Wong et al. 2016). In order to achieve consistency with gridded daily rain gauge of Wong et al. (2011), only CMORPH-CRT data for a period of 9 years from 1998 to 2006 was used in the seasonal mean simulation.

The rain gauge data from 24 meteorological stations with hourly resolution from the year 1998 to 2018 was used to describe diurnal rainfall in Peninsular Malaysia (Figure 1). The name, location and altitude of these meteorological stations are listed in Table 1. Threshold value of $0.2 \mathrm{~mm} /$ hour was used to determine the occurrence of rain (Evans \& Westra 2012; Jamaluddin et al. 2017). Following Jamaluddin et al. (2019) and Richard (2010), we regionalized Peninsular Malaysia into four sub-regions, namely: west coast (WC), foothills of Titiwangsa range (FT), inland-valley (IN), and east coast (EC) of Peninsular Malaysia (Figure 1). For calculating the average values of CMORPH-CRT over a particular sub-region, rainfall estimates in the grid box where the station is located were aggregated. In cases where more than one station appeared in a particular grid box, the value of that grid box was counted more than once, according to the number of stations.

Standard validation statistics was used to validate the performance of CMORPH-CRT rainfall products. The validation statistics used was bias and root mean square error (RMSE). Description of these statistics have been given in many references (Ebert 2007). On the other hand, to illustrate satellite parallax, comparison of CMORPHCRT with ground-based MET Malaysia's radar echoes was also done. Satellite parallax is defined as the apparent shift in a cloud's position as result of the satellite viewing angle 
(Bieliński 2020). Composite of 7 weather radar stations, namely Alor Setar, Bayan Lepas, Kota Bharu, Kluang, Kuantan, Subang and KLIA on $4^{\text {th }}$ November 2017 are used to generate radar echoes. Each radar echoes are in the form of Constant Plan Position Indicator (CAPPI) and each CAPPI grid is interpolated at a constant height of 2 $\mathrm{km}$ from 15 sweeps between $0.7^{\circ}$ and $32^{\circ}$ elevation angle. Each CAPPI has a horizontal resolution of $833 \mathrm{~m}$ at the range of $300 \mathrm{~km}$. The CAPPI is updated in real time every 10 min (Ahmad et al. 2018; Yik et al. 2018).

Over the Peninsular Malaysia, drought is monitored using a tool called Standardized Precipitation Index (SPI). It is based on probability of records for a given amount of rainfall and duration. Positive values of the SPI correspond to rainfall above median, and negative values of the SPI correspond to rainfall below median (Pai et al. 2011). In Peninsular Malaysia, drought conditions can be classified when the SPI values are equal to or below -1.5 . Specifically, for the SPI values -1.5 and below, conditions are classified as 'severely dry' and SPI values -2.0 and below are classified as 'extremely dry'.

The formula is stated as follow:

$$
S P I=\frac{\sum x_{i}-\left(\overline{\sum x_{i j}}\right)}{\sigma}
$$

where $\chi_{i}$ is the monthly rainfall; $\chi_{i j}$ is the long term mean for rainfall; and $\sigma$ is the standard deviation of rainfall.

The amount of SPI from meteorological stations were calculated using the SPI program that can be retrieved at http://drought.unl.edu/MonitoringTools/ DownloadableSPIProgram.aspx (Svoboda et al. 2012). The amount of SPI was then compared to CMORPH-CRT SPI with grid resolution of $25 \mathrm{~km} \times 25 \mathrm{~km}$ which was downloaded from https:/ftp.cpc.ncep.noaa.gov/precip/ PORT/SEMDP/SPI/DATA/.

MET Malaysia has categorised the rainfall intensity in unit of $\mathrm{mm}$ /day as: 1) slight rain when the intensity is below $10 \mathrm{~mm} /$ day; 2) moderate rain when the intensity is between $10 \mathrm{~mm} /$ day and $60 \mathrm{~mm} /$ day; 3) heavy rain when the intensity is between $60 \mathrm{~mm} /$ day and $150 \mathrm{~mm} /$ day; and 4) extreme when the intensity is more than $150 \mathrm{~mm} /$ day (www.met.gov.my). In conjunction with the rainfall intensity category in unit of $\mathrm{mm} /$ day, MET Malaysia also defines it in unit of $\mathrm{mm} /$ hour: 1) slight rain as intensity below $2 \mathrm{~mm} / \mathrm{hr}$; 2) moderate rain as intensity between 2 $\mathrm{mm} / \mathrm{hr}$ and $10 \mathrm{~mm} / \mathrm{hr}$; 3 ) heavy rain as intensity between $10 \mathrm{~mm} / \mathrm{hr}$ and $50 \mathrm{~mm} / \mathrm{hr}$; and 4) violent as intensity more than $50 \mathrm{~mm} / \mathrm{hr}$ (e.g. Jebson 2007).

TABLE 1. List of station names, indicators, locations and altitudes of principal meteorological stations

\begin{tabular}{|c|c|c|c|}
\hline Station name & Station indicator & Location & Altitude (m) \\
\hline Bayan Lepas & 48601 & $5.30 \mathrm{U} 100.27 \mathrm{~T}$ & 2.4 \\
\hline Butterworth & 48602 & $5.47 \mathrm{U} 100.38 \mathrm{~T}$ & 3.3 \\
\hline Alor Setar & 48603 & $6.20 \mathrm{U} 100.40 \mathrm{~T}$ & 3.9 \\
\hline Chuping & 48604 & $6.48 \mathrm{U} 100.27 \mathrm{~T}$ & 21.7 \\
\hline Sitiawan & 48620 & $4.22 \mathrm{U} 100.70 \mathrm{~T}$ & 6.7 \\
\hline Sepang & 48650 & $2.73 \mathrm{U} 101.70 \mathrm{~T}$ & 16.1 \\
\hline Melaka & 48665 & $2.27 \mathrm{U} 102.25 \mathrm{~T}$ & 8.5 \\
\hline Batu Pahat & 48670 & $1.87 \mathrm{U} 102.99 \mathrm{~T}$ & 6.3 \\
\hline Lubok Merbau & 48623 & $4.80 \mathrm{U} 100.90 \mathrm{~T}$ & 77.5 \\
\hline Ipoh & 48625 & $4.57 \mathrm{U} 101.10 \mathrm{~T}$ & 50.1 \\
\hline Cameron Highlands & 48632 & $4.47 \mathrm{U} 101.37 \mathrm{~T}$ & 1545.0 \\
\hline Subang & 48647 & $3.12 \mathrm{U} 101.55 \mathrm{~T}$ & 26.6 \\
\hline Petaling Jaya & 48648 & $3.10 \mathrm{U} 101.65 \mathrm{~T}$ & 60.8 \\
\hline Batu Embun & 48642 & $3.96 \mathrm{U} 102.35 \mathrm{~T}$ & 49.5 \\
\hline Temerloh & 48653 & $3.46 \mathrm{U} 102.38 \mathrm{~T}$ & 39.1 \\
\hline Muadzam Shah & 48649 & $3.05 \mathrm{U} 103.08 \mathrm{~T}$ & 33.3 \\
\hline Kluang & 48672 & $2.02 \mathrm{U} 103.32 \mathrm{~T}$ & 88.1 \\
\hline Senai & 48679 & $1.63 \mathrm{U} 103.67 \mathrm{~T}$ & 37.8 \\
\hline Kota Bharu & 48615 & $6.17 \mathrm{U} 102.28 \mathrm{~T}$ & 4.36 \\
\hline Kuala Krai & 48616 & $5.53 \mathrm{U} 102.20 \mathrm{~T}$ & 58.3 \\
\hline Kuala Terengganu Airport & 48618 & $5.38 \mathrm{U} 103.10 \mathrm{~T}$ & 5.2 \\
\hline Kuala Terangganu Town & 48619 & $5.33 \mathrm{U} 103.13 \mathrm{~T}$ & 35.1 \\
\hline Kuantan & 48657 & $3.78 \mathrm{U} 103.22 \mathrm{~T}$ & 15.23 \\
\hline Mersing & 48674 & $2.45 \mathrm{U} 103.84 \mathrm{~T}$ & 43.6 \\
\hline
\end{tabular}




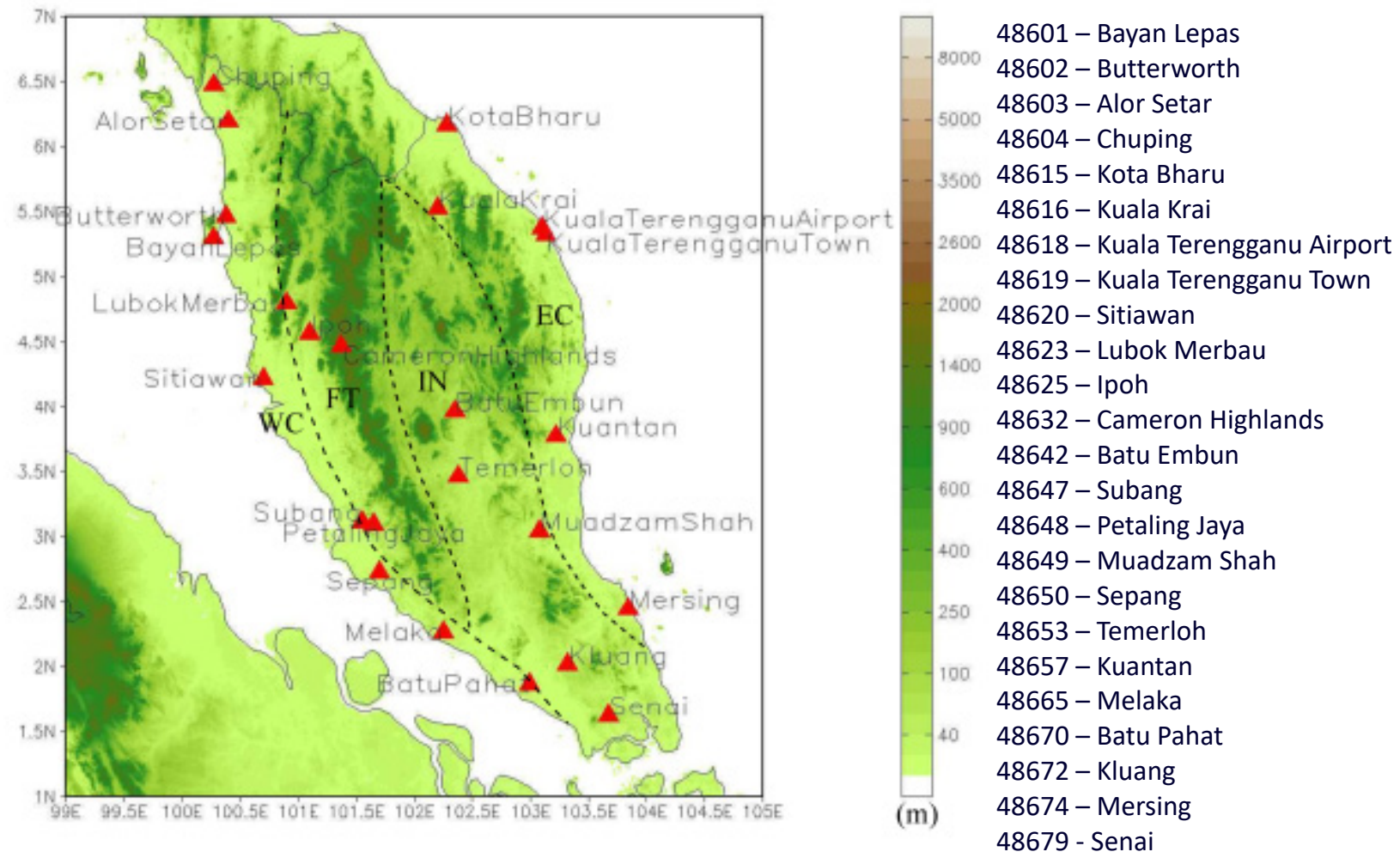

FIGURE 1. The location of the meteorological station and associated World Meteorological Organization (WMO) station indicator. Analysis is categorized into four different sub-regions, namely WC (west coast), FT (foothills of Titiwangsa), IN (inland-valley) and EC (east) coast.

Terrain were plotted using GIBCO 30 arc-second interval grids

\section{RESULTS AND DISCUSSION}

\section{COMPARISON OF SEASONAL RAINFALL}

The comparison of seasonal rainfall spatial distribution of CMORPH-CRT and gridded rain gauge over the Peninsular Malaysia is shown on Figure 2. Generally, the CMORPHCRT compared well to gridded rain gauge data although with a discrepancy in rainfall amount. Over the EC subregion, the higher amount of rainfall during DJF and September-November (SON) was reasonably observed by CMORPH-CRT. Similarly, CMORPH-CRT observed the spatial pattern and increasing amount of rainfall during the inter-monsoon periods (March-May (MAM) and SON) over WC and FT sub-regions. Similar to the gridded rain gauge observation, the relatively drier conditions throughout Peninsular Malaysia during JJA was also feature in CMORPH-CRT. However, from Figure 2i-1, CMORPH-CRT tended to produce wet bias over inlandvalley (IN sub-region) and dry bias in coastal (WC and EC sub-region) and mountainous (FT sub-region) area of the
Peninsular Malaysia. The wet bias over IN sub-region is generally the highest during DJF with $4 \mathrm{~mm} /$ day compared to about $2 \mathrm{~mm} /$ day in other seasons. Likewise, in DJF, a dry bias is more pronounced over EC sub-region with -4 $\mathrm{mm}$ /day and during inter-monsoon periods over the FT sub-region with $-3 \mathrm{~mm} /$ day.

The bias between the CMORPH-CRT and individual rain gauge annual cycles in Peninsular Malaysia are shown in Figure 3(a). Overall, the annual evolution of rainfall in CMORPH-CRT shows a high consistency with rain gauge, as indicated by low bias of $\pm 1 \mathrm{~mm} /$ day. However, during the month of November and December, and over the EC and IN sub-regions i.e., the area where the rainfall is highest, bias was higher with values of $\pm 2 \mathrm{~mm} /$ day. In addition to the bias, the RMSEs of the CMORPH-CRT and rain gauge annual rainfall cycle are shown in Figure 3(b). The results show that the CMORPHCRT tend to have smaller RMSE values $(<15 \mathrm{~mm} /$ day $)$ during dry season (JJA) and higher RMSE values during wet season (November to December) with values > 
$35 \mathrm{~mm} /$ day. Interestingly, CMORPH-CRT tend to have larger RMSE over the EC sub-region compared to IN sub-region during the period. EC sub-region experienced more rainfall than IN sub-region during November to December. This indicated that the CMORPH-CRT tend to have larger error during high rainfall events.

Area-averaged daily CMORPH-CRT cross validated with area-averaged daily rain gauge over the 4 subregions, focusing on different location and thus, different topography in Peninsular Malaysia, is shown on Figure 4. The CMORPH-CRT showed the largest agreement with rain gauge over the WC and EC sub-regions. On the other hand, CMORPH-CRT underestimates rainfall over the FT sub-region, while it overestimates over IN subregion which is characterised by low-land area between Titiwangsa and Tahan mountain range (Figure 4). This indicates that the performance of CMORPH-CRT is also dependent on the elevation. It can be assumed that the underestimation of heavy rainfall over FT sub-region is due to shallow orographic convection instead of deep convection by CMORPH-derived rainfall algorithms (Kubota et al. 2009; Shige \& Kummerow 2016; Shige et al. 2013). Similarly, non-raining cirrus with cold cloudtop temperatures system that is usually observed as rain over low terrain may be attributed to the overestimation of rainfall over the IN sub-region.
The results from both the spatial rainfall climatology and annual cycles show that the CMORPH-CRT compares well to the rain gauge although with a noted discrepancy based on location and in the amount of rainfall. In general, the CMORPH-CRT performed best over the coastal areas with moderate rainy events. On the other hand, larger error was associated to high amount of rainfall over complex terrain. The performance of CMORPH-CRT in observing the seasonal rainfall characteristic in Peninsular Malaysia is consistent with that of the CMORPH that was described in Soo et al. (2019) over river basins in Peninsular Malaysia during northeast monsoon, Jamandre and Narisma (2013) over the Philippines and Trinh-Tuan et al. (2019) over Central Vietnam.

\section{EXTREME WEATHER MONITORING USING CMORPH-CRT PRODUCTS HEAVY RAINFALL EVENT OVER PENANG ON $4^{\mathrm{TH}}$ NOVEMBER 2017}

Penang is vulnerable to flash floods every time heavy rains occur. On $4^{\text {th }}$ November 2017 , the entire Penang Northeast and Southwest districts in the island as well as North, Central and South Seberang Perai in the mainland was flooded. Heavy rain for 17 hours with strong winds caused the road system to be paralyzed, thousands of houses flooded, and hundreds of fallen trees. In addition, this heavy rain led to landslide incidents over some areas. (a)

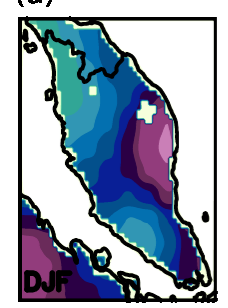

(c)

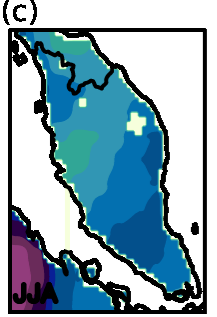

(b)

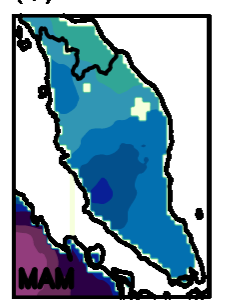

(d)

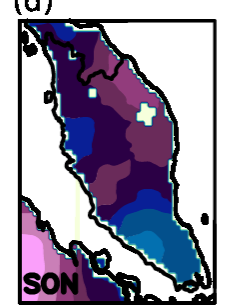

(e)

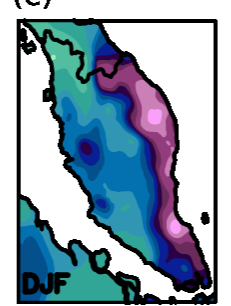

(g)

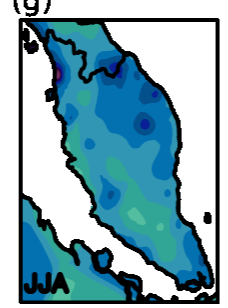

(f)

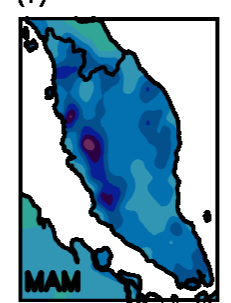

(h)

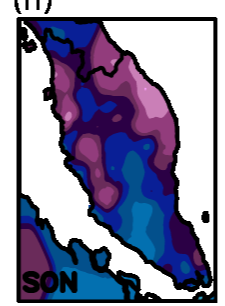

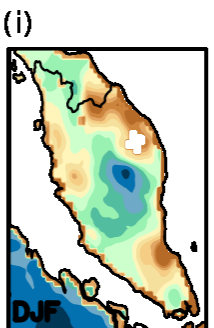

(k)

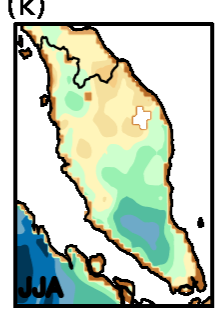

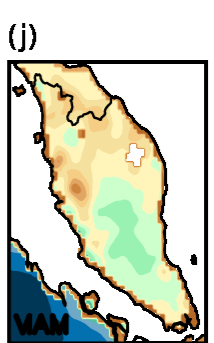

(I)

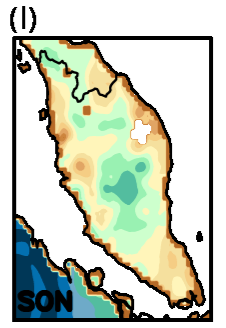

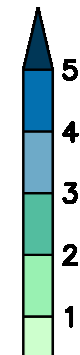

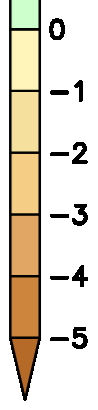

\subsection{1 .523344566788910121416} $\mathrm{mm} /$ day

FIGURE 2. Seasonal mean of daily average rainfall (mm/day) (a) - (d) CMORPH-CRT, (e) - (f) gridded rain gauge and (i) $-(\mathrm{k})$ biases between CMORPH-CRT and gridded rain gauge 
As a result, more than 8000 people were evacuated to flood evacuation centers and 7 people died throughout the state (Davies 2017). Hence, a few rain gauge stations were selected in this study, namely Bayan Lepas and Butterworth in Penang to capture heavy rainfall amount, while Batu Pahat and Kluang in Johor for slight rain downpour. The aim of this case study is to determine whether the CMORPH-CRT can observe reliable amount of heavy rainfall over the Peninsular Malaysia.

\section{a. Bias}

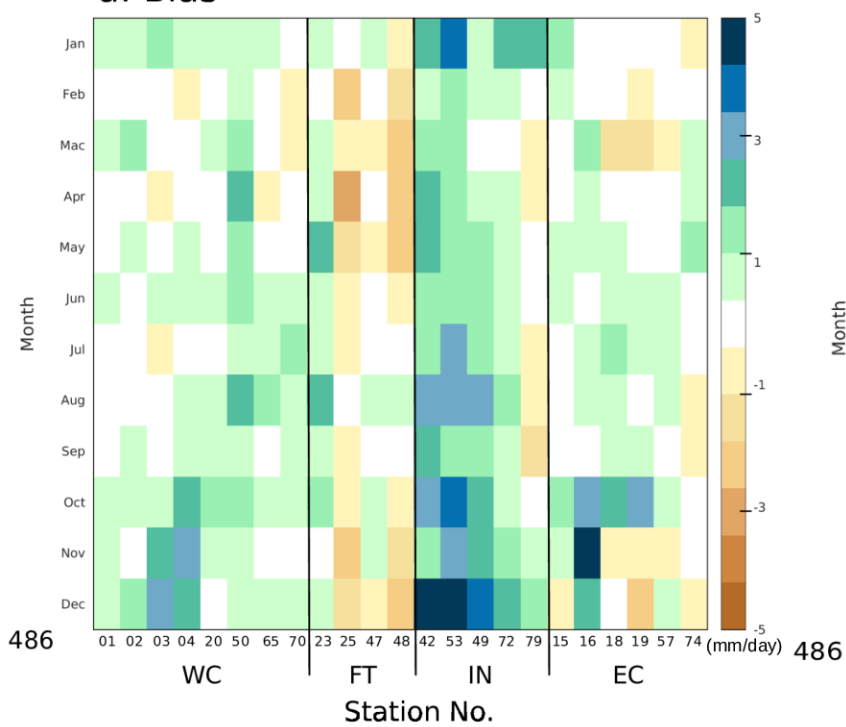

The unusual heavy rainfall on $4^{\text {th }}$ November 2017 was due to the formation of a low-pressure system over northern Peninsular Malaysia. On the day of incident, this low-pressure system did not move across Peninsular Malaysia, instead it was quasi-stationary for 17 hours around the state of Penang. The weakening of Typhon Damrey due to landfall over Vietnam produced the Fujiwhara effect which enhanced low-pressure system in Penang (Penang Kini on $8^{\text {th }}$ November 2017; AstroAwani

\section{b. RMSE}

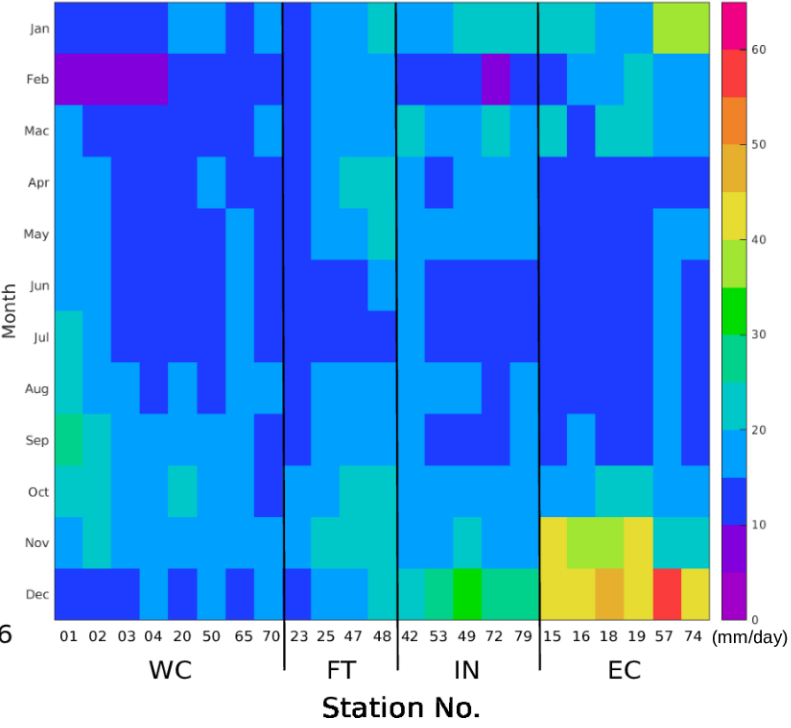

FIGURE 3. Annual cycles of a) bias and b) RMSE between CMORPH-CRT and individual rain gauge station over Peninsular Malaysia
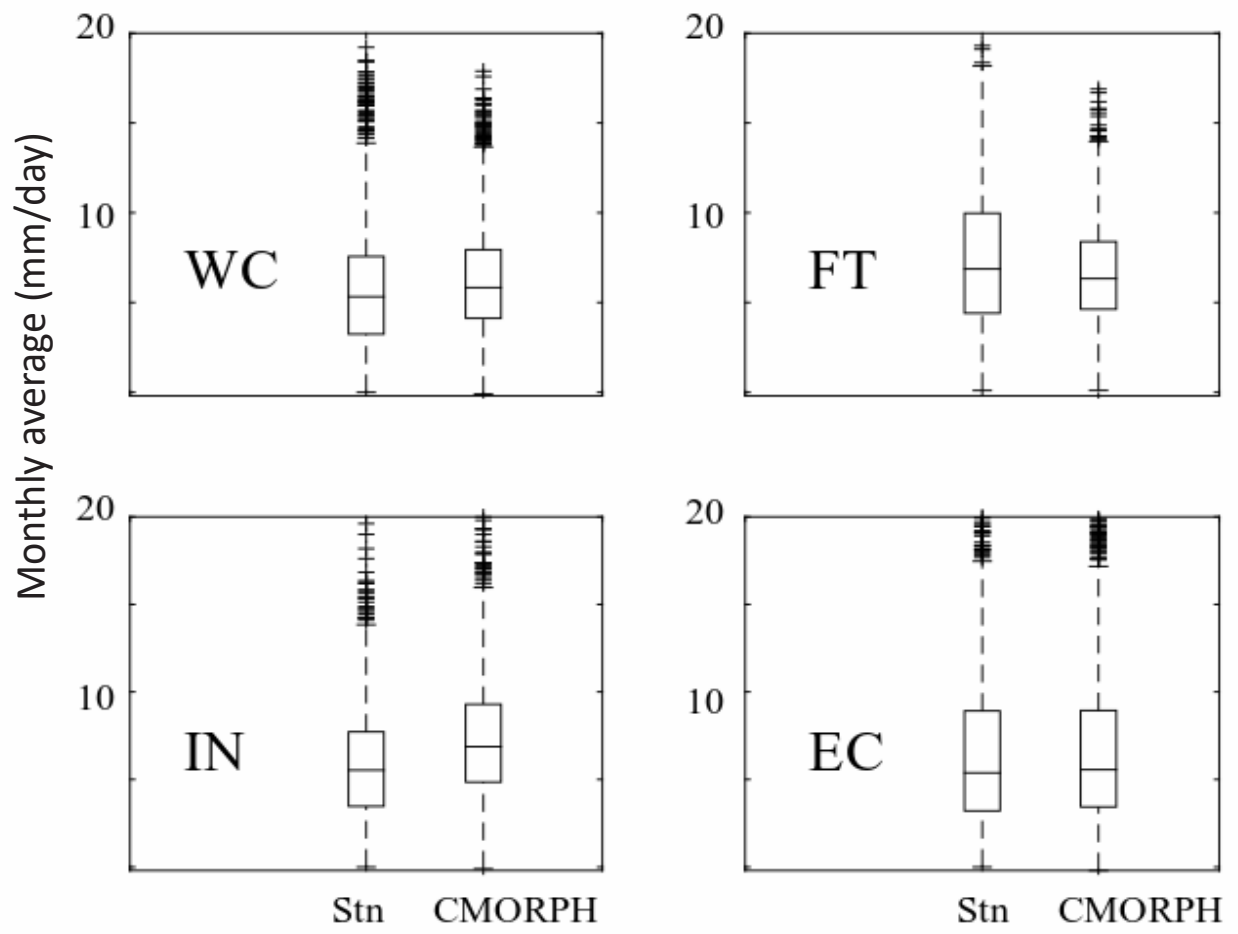

FIGURE 4. Boxplots showing comparison of monthly average variance ( $\mathrm{mm} /$ day) over (a) WC sub-region, (b) FT sub-region, (c) IN sub-region, and (d) EC sub-region between rain gauge and CMORPH-CRT. Stn. are referring to all rain gauge stations which located within their respective sub-regions 
on $7^{\text {th }}$ November 2017). The locations of the CMORPHCRT low-pressure systems was almost similar with MET Malaysia's radar echoes (Figure 5). Figure 5(a) shows the image of CMORPH-CRT and radar echo at 0900 MST $4^{\text {th }}$ November 2017 at the initial stage of low-pressure system formation. The system matures at $1300 \mathrm{MST}$ and the condition was maintained over the state of Penang until 2100 MST (Figure 5).

The analysis is carried out with comparison between CMORPH-CRT and rain gauge data over Butterworth, Bayan Lepas, Batu Pahat and Kluang meteorological stations. The results show that the CMORPH-CRT compared relatively well to rain gauge although it underestimates heavy rainfall and overestimates light rainfall. For heavy rainfall, Butterworth rain gauge recorded $50.4 \mathrm{~mm} / \mathrm{hr}$ compared to $25.9 \mathrm{~mm} / \mathrm{hr}$ for CMORPH-CRT (reduction of $24.5 \mathrm{~mm} / \mathrm{hr}$ or $49 \%$ ) at 0900 MST and Bayan Lepas rain gauge recorded $47.0 \mathrm{~mm} / \mathrm{hr}$ compared to $19.0 \mathrm{~mm} / \mathrm{hr}$ for CMORPH-CRT at $1200 \mathrm{MST}$ (reduction of $28 \mathrm{~mm} / \mathrm{hr}$ or $59 \%$ ). On the other hand, for light rainfall, the Kluang rain gauge recorded $1.5 \mathrm{~mm} /$ $\mathrm{hr}$ compared to $3.1 \mathrm{~mm} / \mathrm{hr}$ for CMORPH-CRT at 0500 MST (increase of $1.6 \mathrm{~mm} / \mathrm{hr}$ or $101 \%$ ) and Batu Pahat rain gauge recorded $4.2 \mathrm{~mm} / \mathrm{hr}$ at $0300 \mathrm{MST}$ compared to longer rainy hours with total amount of $4.4 \mathrm{~mm} / \mathrm{hr}$ for CMORPH-CRT (increase of $0.2 \mathrm{~mm} / \mathrm{hr}$ or $5 \%$ ) as shown on Table 2.

The performance of CMORPH-CRT in observing heavy rainfall over Peninsular Malaysia is comparable to Integrated Multi-satellite Retrievals for Global Precipitation Measurement (GPM) and other satellite precipitation products such as Global Precipitation Climatology Project (GPCP), GSMaP, TRMM and PERSIANN (Mahmud et al. 2016; Soo et al. 2020, 2019; Tan et al. 2015). Mahmud et al. (2016) found that GPM tend to underestimate heavy rainfall ( $>50 \mathrm{~mm} /$ day $)$ and overestimate slight to moderate rainfall $(\sim 10 \mathrm{~mm} /$ day to $55 \mathrm{~mm} /$ day). Tan et al. (2015) found that the satellite precipitation products i.e. GPCP, CMORPH, TRMM and PERSIANN had the tendency to overestimate slight to moderate rainfall $(1 \mathrm{~mm} /$ day $<$ rain $<20 \mathrm{~mm} /$ day $)$ and to underestimate heavy rainfall ( $>20 \mathrm{~mm} /$ day) over the Peninsular Malaysia. The GPCP and CMORPH tend to underestimate heavy rainfall by $2.8 \%$ and $13.2 \%$, respectively (Tan et al. 2015). On the other hand, Soo et al. (2019) found that the TRMM, CMORPH and PERSIANN had shown an acceptable accuracy in capturing heavy rainfall in Sungai Kelantan basin during the northeast monsoon. However, the accuracy was decreased to about 50-60\% over Langat and 30-40\% for Sungai Johor basin. Soo et al. (2020) investigated the capability of bias correction i.e. linear scaling, local intensity scaling and power transformation schemes in improving CMORPH, TRMM and PERSIANN estimations over Sungai Langat basin during the northeast monsoon. They found that all of the bias correction schemes are able to improve satellite estimations except PERSIANN with local intensity scaling scheme. (a)

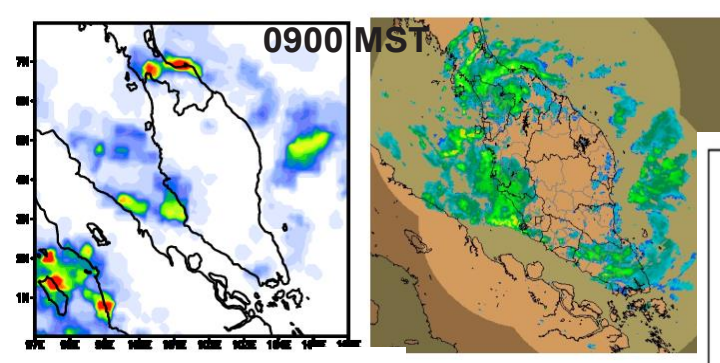

(c)
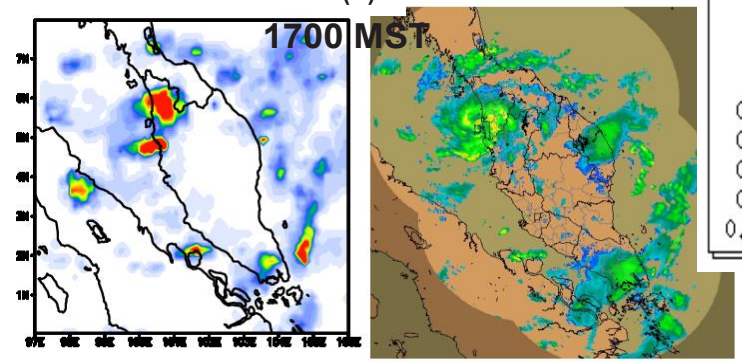

04 Nov. 2017

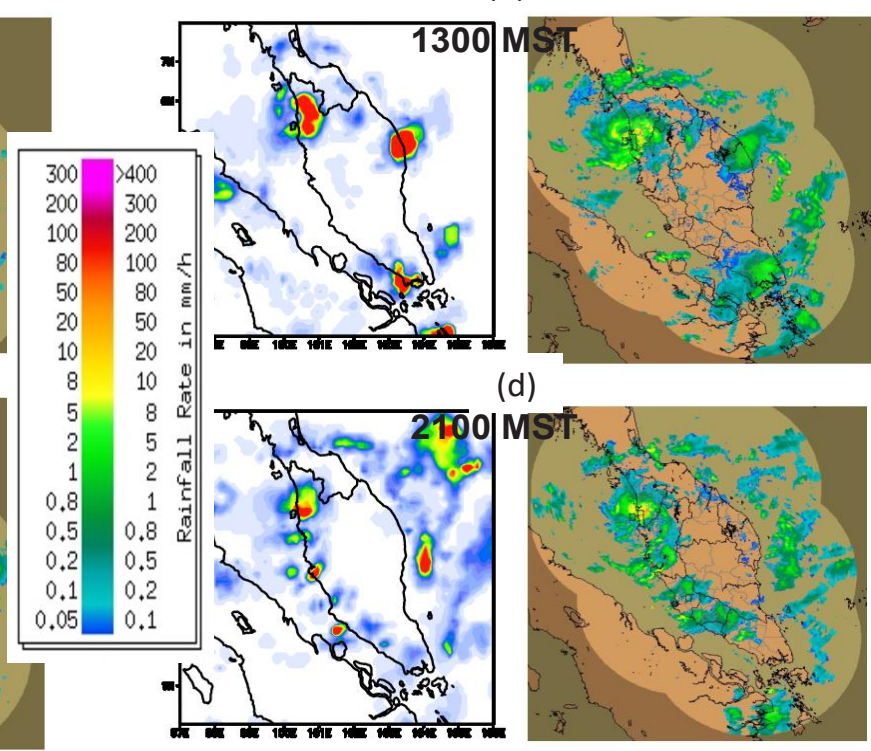

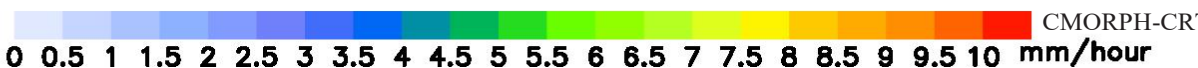

FIGURE 5. Comparison of CMORPH-CRT and radar echoes during (a) 0900 MST, (b) 1300 MST, (c) 1700 MST and (d) $2100 \mathrm{MST}$ on 4th November 2017 
TABLE 2. Amount of rainfall ( $\mathrm{mm} / \mathrm{hr})$ at selected locations in Peninsular Malaysia on $4^{\text {th }}$ November 2017

\begin{tabular}{|c|c|c|c|c|c|c|c|c|}
\hline \multirow{2}{*}{$\begin{array}{l}\text { Hour } \\
\text { (MST) }\end{array}$} & \multicolumn{2}{|c|}{ Bayan Lepas } & \multicolumn{2}{|c|}{ Butterworth } & \multicolumn{2}{|c|}{ Batu Pahat } & \multicolumn{2}{|c|}{ Kluang } \\
\hline & RG & $\mathrm{C}-\mathrm{C}$ & $\mathrm{RG}$ & $\mathrm{C}-\mathrm{C}$ & RG & $\mathrm{C}-\mathrm{C}$ & $\mathrm{RG}$ & $\mathrm{C}-\mathrm{C}$ \\
\hline 00:00 & 0.8 & 0.1 & 0.2 & 0.1 & 0.0 & 0 & 0.0 & 0 \\
\hline 01:00 & 5.4 & 0.2 & 0.0 & 0 & 0.0 & 0 & 0.0 & 0 \\
\hline 02:00 & 0.0 & 0 & 0.0 & 0 & 0.0 & 0 & 0.0 & 0 \\
\hline 03:00 & 0.2 & 0 & 0.0 & 0 & 4.2 & 0.5 & 0.0 & 0.4 \\
\hline 04:00 & 0.0 & 0.3 & 0.6 & 0.1 & 0.0 & 1.1 & 0.0 & 0.7 \\
\hline 05:00 & 0.0 & 1.1 & 13.4 & 1.8 & 0.0 & 0.5 & 1.5 & 3.1 \\
\hline 06:00 & 0.8 & 2.2 & 25.4 & 10.7 & 0.0 & 1.6 & 0.0 & 1.2 \\
\hline 07:00 & 1.2 & 3 & 18.4 & 2.4 & 0.0 & 0.7 & 0.0 & 0.2 \\
\hline 08:00 & 4.6 & 4 & 26.2 & 7.2 & 0.0 & 0 & 0.0 & 0 \\
\hline 09:00 & 12.0 & 6.3 & 50.4 & 25.9 & 0.0 & 0 & 0.0 & 0 \\
\hline $10: 00$ & 24.0 & 10.4 & 26.4 & 12.1 & 0.0 & 0 & 0.0 & 0 \\
\hline $11: 00$ & 25.0 & 12.2 & 31.0 & 9.1 & 0.0 & 0 & 0.0 & 0 \\
\hline $12: 00$ & 47.0 & 19.0 & 18.0 & 6.2 & 0.0 & 0 & 0.0 & 0 \\
\hline $13: 00$ & 12.8 & 5.7 & 12.0 & 4.3 & 0.0 & 0 & 0.0 & 0 \\
\hline $14: 00$ & 7.2 & 2.9 & 2.0 & 3.4 & 0.0 & 0 & 0.0 & 0 \\
\hline $15: 00$ & 5.6 & 3.2 & 3.4 & 5.6 & 0.0 & 0 & 0.0 & 0 \\
\hline $16: 00$ & 15.6 & 3.8 & 6.2 & 4.4 & 0.0 & 0 & 0.0 & 0 \\
\hline $17: 00$ & 14.8 & 5.8 & 17.2 & 6.7 & 0.0 & 0 & 0.0 & 0 \\
\hline $18: 00$ & 18.4 & 6.9 & 29.0 & 11 & 0.0 & 0 & 0.0 & 0 \\
\hline 19:00 & 15.0 & 4.9 & 33.0 & 19.3 & 0.0 & 0 & 0.0 & 0 \\
\hline $20: 00$ & 2.4 & 5 & 49.8 & 20.1 & 0.0 & 0 & 0.0 & 0 \\
\hline $21: 00$ & 0.4 & 6.2 & 12.2 & 8 & 0.0 & 0 & 0.0 & 0 \\
\hline $22: 00$ & 0.8 & 2 & 4.8 & 2.2 & 0.0 & 0 & 0.0 & 0 \\
\hline $23: 00$ & 0.6 & 1.6 & 3.6 & 1.7 & 0.0 & 0 & 0.0 & 0 \\
\hline
\end{tabular}

*RG - Rain gauge; C-C - CMORPH-CRT

DROUGHT IN PENINSULAR MALAYSIA DURING FEBRUARY AND MARCH 2014

SPI is strongly influenced by the recorded rainfall (Wu et al. 2005; Zin et al. 2013). For the rain gauge, long term mean rainfall is based on 30 years of data i.e. January 1981 to December 2010, while it is 13 years i.e. from January 1998 to December 2010 for CMORPH-CRT. The month of February and March 2014 was chosen for meteorological drought analysis with the SPI period for 1, 2 and 3 months for rain gauge, while 30, 60 and 90 days, respectively, for CMORPH-CRT.

Based on analysis of the rain gauge SPI, during February 2014, drought condition was observed and continued for 3 months (December 2013 to February 2014) over Melaka and Sitiawan, 2 months (January 2014 to February 2014) over Alor Setar, Chuping, Lubuk 
Merbau, Subang, Sepang, Kuala Pilah, Melaka, Batu Pahat and Kluang. All these stations were located over WC and FT sub-regions. Drought period of 1 month (February 2014) was observed elsewhere except over Ipoh, Cameron Highlands and Batu Pahat (located over FT sub-region) and, Batu Embun, Kuala Terengganu and Kuantan (located over IN and EC sub-regions). For CMORPH-CRT SPI, the drought condition was observed and continued for 3 months over Melaka, 2 months over WC and FT sub-regions and 1 month elsewhere except over Cameron Highlands and Batu Pahat (FT sub-region; Figure 6(e)). In general, CMORPH-CRT SPI was consistent but extremely dry especially for 1 month SPI compared with the rain gauge SPI. The rain gauge amount of rainfall that was much below the area-average long term mean of February modulates severely dry condition (SPI < -1.5) over most areas in the Peninsular Malaysia (Figure 6(a)-6(c); Figure 8(b)). Area-average long term mean for January, February and March over Peninsular Malaysia is $5.3 \mathrm{~mm} /$ day, $3.9 \mathrm{~mm} /$ day and $4.6 \mathrm{~mm} /$ day, respectively. In conjunction with rain gauge amount of rainfall that was much below the area-average long term mean of February, CMORPH-CRT showed much lower amount of rainfall (Figure 8(b)). This therefore modulates extremely dry condition (SPI $<-2.0$ ) over most of the areas in Peninsular Malaysia (Figure 6(a)).

During March 2014, the areas and severity of drought condition were reduced. The amount of rainfall that exceeded or fell within average long term mean of March reduced 1 month SPI to neutral in both data sets except rain gauge over Melaka and Ipoh (Figure 7; Figure $8(\mathrm{c})$ ). On the other hand, the amount of rainfall that was much below the area-average long term mean of February has caused the 2 month (60 days for CMORPH-CRT) SPI to maintain drought condition over some part in WC and FT sub-regions (Figure 7(b); Figure 8(b)). Similar condition was observed for 3-month (90 days for CMORPH-CRT) SPI (Figure 7(c); Figure 8(a)).

In general, the CMORPH-CRT and rain gauge SPI values are in agreement, thus both show drought condition (a) 30 days

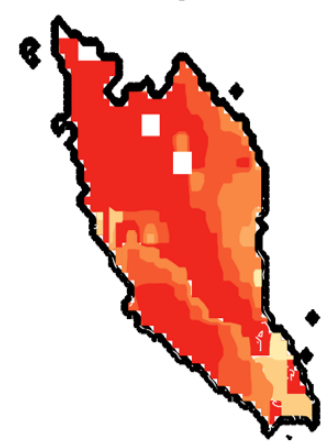

(d)

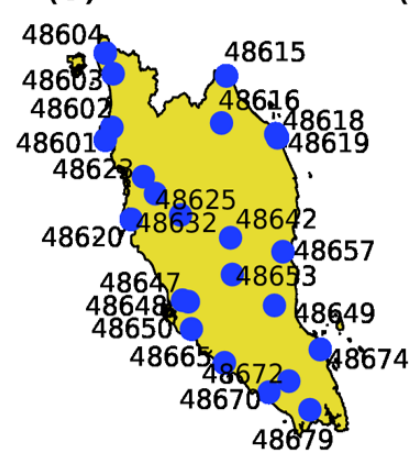

(b) 60 days

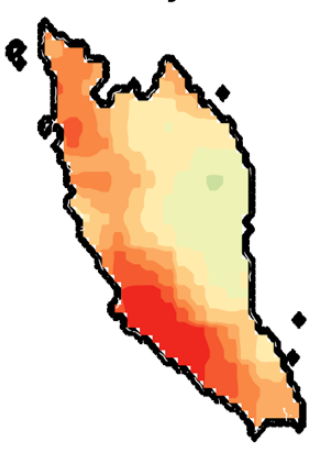

(c) 90 days

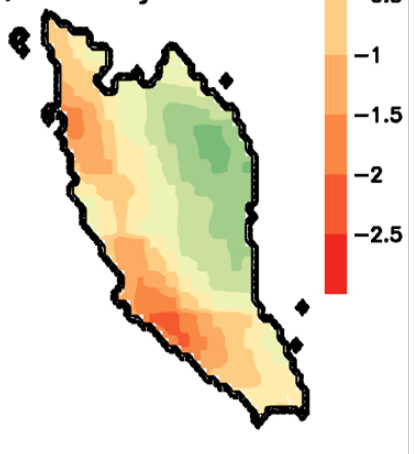

(e)

\begin{tabular}{|l|l|l|l|l|c|}
\hline \multirow{2}{*}{ Stn No } & \multirow{2}{*}{ Lat } & Lon & \multicolumn{3}{|c|}{ SPI } \\
\cline { 4 - 6 } & & & 1month & 2month & 3month \\
\hline 48601 & 5.30 & 100.27 & -1.43 & -0.98 & -1.18 \\
\hline 48602 & 5.45 & 100.38 & -1.77 & 0.02 & -0.81 \\
\hline 48603 & 6.20 & 100.40 & -1.71 & -1.67 & -0.81 \\
\hline 48604 & 6.48 & 100.27 & -1.30 & -1.67 & -1.51 \\
\hline 48615 & 6.17 & 102.30 & -1.83 & -1.02 & -1.08 \\
\hline 48616 & 5.53 & 102.20 & -1.58 & 0.01 & 0.12 \\
\hline 48618 & 5.38 & 103.10 & -1.90 & -1.16 & -0.59 \\
\hline 48620 & 4.22 & 100.70 & -1.49 & -0.33 & 0.00 \\
\hline 48623 & 4.80 & 100.90 & -1.66 & -1.73 & -2.25 \\
\hline 48625 & 4.57 & 101.10 & -1.19 & -0.22 & -0.85 \\
\hline 48632 & 4.47 & 101.37 & -1.25 & -1.08 & -0.48 \\
\hline 48642 & 3.97 & 102.35 & -1.20 & -0.90 & -0.25 \\
\hline 48647 & 3.13 & 101.55 & -3.61 & -1.92 & -0.73 \\
\hline 48648 & 3.10 & 101.65 & -1.99 & -1.03 & 0.45 \\
\hline 48649 & 3.05 & 103.08 & -1.65 & -1.62 & 0.19 \\
\hline 48650 & 2.73 & 101.70 & -2.78 & -1.70 & -1.44 \\
\hline 48653 & 3.47 & 102.38 & -1.67 & -2.16 & -0.12 \\
\hline 48657 & 3.77 & 103.22 & -1.11 & -0.42 & 0.69 \\
\hline 48665 & 2.27 & 102.25 & -2.18 & -1.95 & -1.54 \\
\hline 48670 & 1.87 & 102.98 & -0.35 & -1.21 & -0.38 \\
\hline 48672 & 2.02 & 103.32 & -2.02 & -2.68 & -0.65 \\
\hline 48674 & 2.45 & 103.83 & -1.84 & -0.88 & -0.57 \\
\hline 48619 & 5.33 & 103.13 & -1.47 & -0.76 & -0.57 \\
\hline 48679 & 1.63 & 103.67 & -1.28 & -1.27 & -0.14 \\
\hline & & & & & \\
\hline
\end{tabular}

FIGURE 6. Comparison of SPI Drought Map for February 2014 based from (a) 30 days CMORPH-CRT, (b) 60 days CMORPH-CRT, (c) 90 days CMORPH-CRT, (d) location of meteorological stations and (e) rain gauge data over Peninsular Malaysia 
over Peninsular Malaysia. However, it should be noted that CMORPH-CRT SPI tend to observe drier SPI than rain gauge over the region. This drier CMORPH-CRT SPI is consistent with that of the TRMM SPI that was described in Tan et al. (2017) over the Sungai Kelantan basin. (a) 30 days

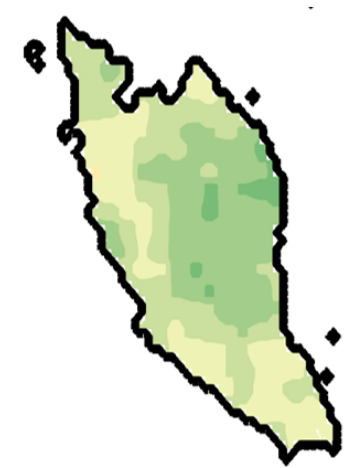

(b) 60 days

(c) 90 days
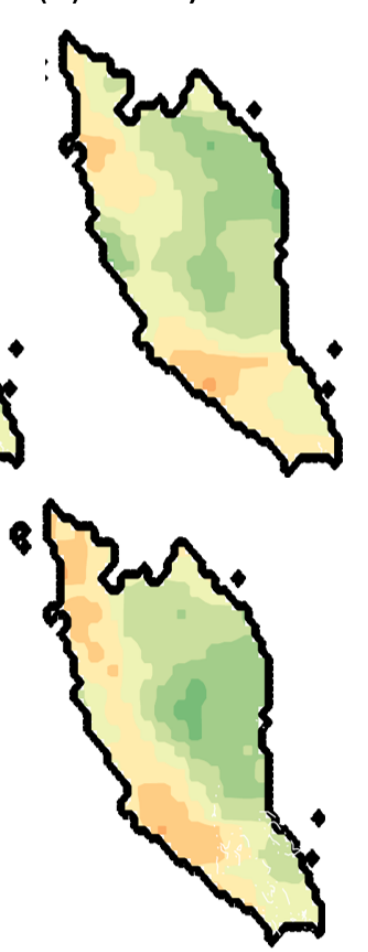

(d)

\begin{tabular}{|c|c|c|c|c|c|}
\hline \multirow{2}{*}{ Stn No } & \multirow{2}{*}{ Lat } & \multirow{2}{*}{ Lon } & \multicolumn{3}{|c|}{ SPI } \\
\hline & & & 1month & 2month & 3month \\
\hline 48601 & 5.30 & 100.27 & -0.48 & -1.30 & -1.26 \\
\hline 48602 & 5.45 & 100.38 & -0.66 & -1.61 & -0.51 \\
\hline 48603 & 6.20 & 100.40 & -0.71 & -1.36 & -1.66 \\
\hline 48604 & 6.48 & 100.27 & -1.23 & -1.54 & -2.05 \\
\hline 48615 & 6.17 & 102.30 & -0.44 & -1.03 & -1.10 \\
\hline 48616 & 5.53 & 102.20 & 0.44 & -0.36 & 0.07 \\
\hline 48618 & 5.38 & 103.10 & -0.84 & -1.37 & -1.38 \\
\hline 48620 & 4.22 & 100.70 & -0.60 & -1.37 & -0.60 \\
\hline 48623 & 4.80 & 100.90 & -0.09 & -1.09 & -1.32 \\
\hline 48625 & 4.57 & 101.10 & -2.39 & -2.37 & -1.15 \\
\hline 48632 & 4.47 & 101.37 & -0.66 & -1.09 & -1.03 \\
\hline 48642 & 3.97 & 102.35 & 0.09 & -0.57 & -0.58 \\
\hline 48647 & 3.13 & 101.55 & -0.56 & -1.94 & -1.69 \\
\hline 48648 & 3.10 & 101.65 & -0.91 & -1.89 & -1.40 \\
\hline 48649 & 3.05 & 103.08 & -0.10 & -1.06 & -1.42 \\
\hline 48650 & 2.73 & 101.70 & -0.78 & -1.87 & -1.61 \\
\hline 48653 & 3.47 & 102.38 & -1.17 & -1.84 & -2.15 \\
\hline 48657 & 3.77 & 103.22 & -1.13 & -1.84 & -0.87 \\
\hline 48665 & 2.27 & 102.25 & -1.65 & -2.67 & -2.69 \\
\hline 48670 & 1.87 & 102.98 & 0.37 & -0.05 & -0.67 \\
\hline 48672 & 2.02 & 103.32 & 0.07 & -0.87 & -1.53 \\
\hline 48674 & 2.45 & 103.83 & -0.15 & -1.28 & -0.99 \\
\hline 48619 & 103.13 & 5.33 & -1.05 & -1.69 & -1.22 \\
\hline 48679 & 1.63 & 103.67 & -0.62 & -1.38 & -1.39 \\
\hline
\end{tabular}

FIGURE 7. Comparison of SPI Drought Map for March 2014 based from (a) 30 days CMORPH-CRT, (b) 60 days CMORPH-CRT, (c) 90 days CMORPH-CRT and (d) rain gauge data over Peninsular Malaysia

\section{CONCLUSION}

In this study, CMORPH-CRT product is compared to rain-gauge observation over different sub-regions, thus representing different topography in Peninsular Malaysia. The overall results show that the CMORPHCRT agreed with the rain gauge although with noted discrepancy due to geographical terrain and rainfall intensity category. The CMORPH-CRT performed best over coastal sub-regions but underestimated over FT sub-region and overestimated at the IN sub-region. The CMORPH-CRT also tend to perform better in moderate rather than heavy rainfall events.
The performance of the CMORPH-CRT has been further explored to analyzed extreme rainfall and drought conditions that occurred on $4^{\text {th }}$ November 2017 and February to March 2014, respectively. CCMORPHCRT is capable of observing the formation and decay of low-pressure systems in Penang on $4^{\text {th }}$ November 2017. However, the amount of rainfall is less than half from the rain-gauge. The assessment results for drought condition during February and March 2014 have shown that the CMORPH-CRT and rain gauge are in agreement when monitoring the SPI index, and thus, for determining drought conditions over the Peninsular Malaysia. 

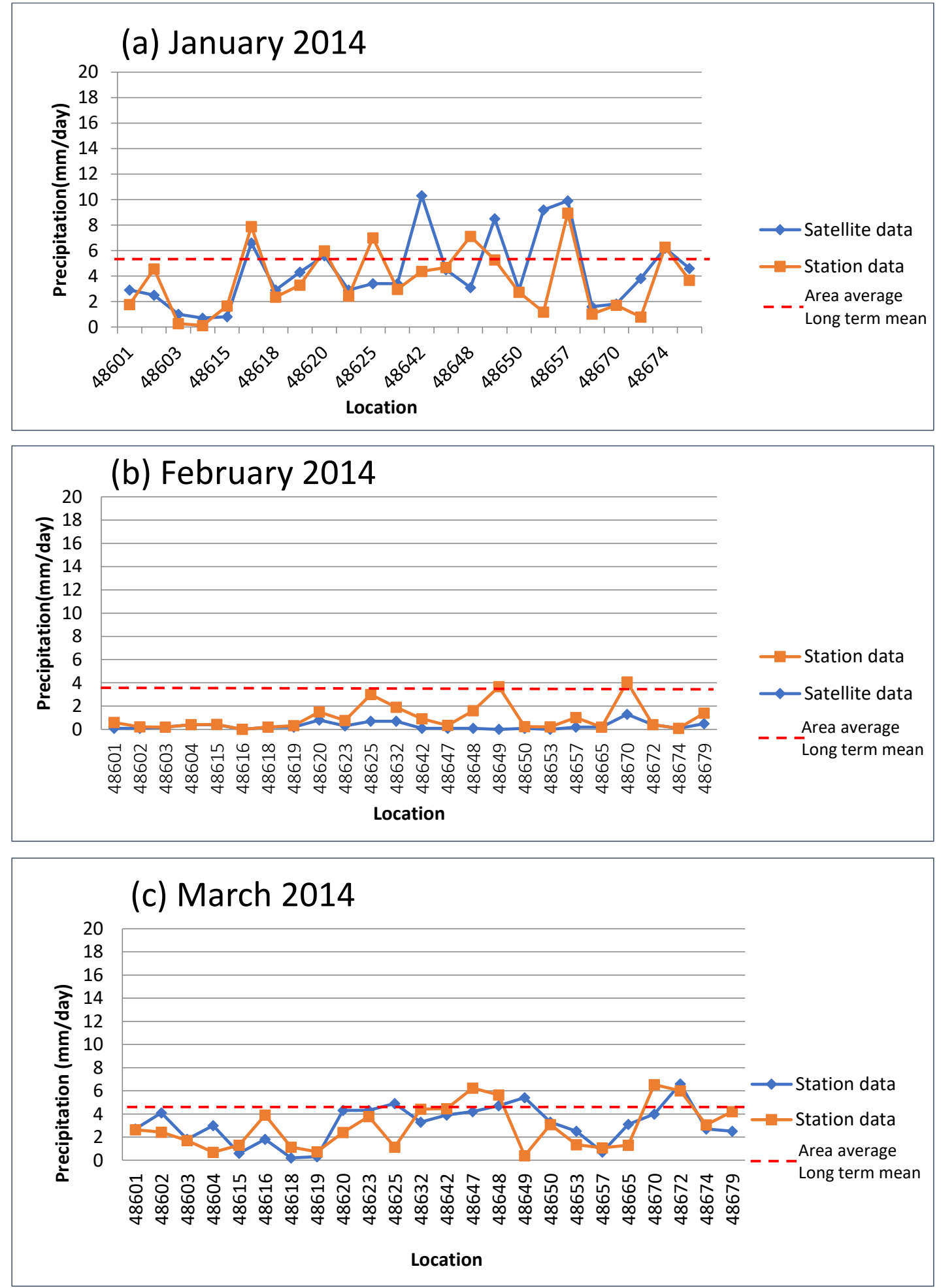

FIGURE 8. Average monthly rainfall ( $\mathrm{mm} /$ day) over selected locations during (a) January, (b) February and (c) March 2014 
The near real-time observations and accurate measurements of rainfall are the criteria needed to enable satellite-derived rainfall to be used as operational extreme weather monitoring tool. Considering the latency of $2 \mathrm{~h}$ and the accuracy of the rainfall measurements that comparable to others, CMORPH-CRT is the best option to choose as a space-based weather extreme monitoring tool compared to other satellite-derived rainfall and ground-based precipitation products over the Peninsular Malaysia. Currently, an intranet local website, called Space-based Weather and Climate Extremes Monitoring Project that is based on CMORPH-CRT data has been established and is being updated every hour. Future works to enhance the accuracy of rainfall amount will be implemented in the project by bias correction the CMORPH-CRT data with in-situ rain gauge observations.

\section{REFERENCES}

Ahmad, F., Sahrin, M., Kamiluddin, A. \& Wahab, A.A. 2018. Comparison of CAPPI Height $2 \mathrm{~km}$ and $1 \mathrm{~km}$ during Northeast Monsoon. Technical Report: Malaysian Meteorological Department.

Ashouri, H., Hsu, K.L., Sorooshian, S., Braithwaite, D.K., Knapp, K.R., Cecil, L.D., Nelson, B.R. \& Prat, O.P. 2015. PERSIANN-CDR: Daily precipitation climate data record from multisatellite observations for hydrological and climate studies. Bulletin of the American Meteorological Society 96(1): 69-83. doi:10.1175/BAMS-D-13-00068.1

AstroAwani. Fenomena Fujiwhara Punca Banjir di Pulau Pinang. https://www.astroawani.com/berita-malaysia/ fenomena-fujiwara-punca-banjir-di-pulau-pinang-159859. Accessed on September 13, 2020.

Ayoub, A.B., Tangang, F., Juneng, L., Tan, M.L. \& Chung, J.X. 2020. Evaluation of gridded precipitation datasets in Malaysia. Remote Sensing 12(4): 613. doi:10.3390/ rs12040613

Bieliński, T. 2020. A parallax shift effect correction based on cloud height for geostationary satellites and radar observations. Remote Sensing 12(3): 365. doi:10.3390/rs12030365

Buurman, J., Dahm, R. \& Goedbloed, A. 2014. Monitoring and early warning systems for droughts: Lessons from floods. SSRN Electronic Journal (January 2014). doi:10.2139/ ssrn. 2518758

Chang, C.P., Harr, P.A. \& Chen, H.J. 2005. Synoptic disturbances over the equatorial South China sea and Western maritime continent during boreal winter. Monthly Weather Review 133(3): 489-503. doi:10.1175/MWR-2868.1

Davies, R. 2017. Malaysia - Severe Storm and Floods Leave 7 Dead, 10,000 Displaced. https://floodlist.com/asia/malaysiapenang-kedah-floods-november-2017.

Duan, Z., Liu, J., Tuo, Y., Chiogna, G. \& Disse, M. 2016. Evaluation of eight high spatial resolution gridded precipitation products in Adige Basin (Italy) at multiple temporal and spatial scales. Science of the Total Environment 573: 1536-1553. doi:10.1016/j.scitotenv.2016.08.213

Ebert, E.E. 2007. Methods for verifying satellite precipitation estimates. In Measuring Precipitation from Space. Advances in Global Change Research, vol 28, edited by Levizzani, V., Bauer, P. \& Turk, F.J. Dordrecht: Springer. pp. 345-356.

Evans, J.P. \& Westra, S. 2012. Investigating the mechanisms of diurnal rainfall variability using a regional climate model. Journal of Climate 25(20): 7232-7247. doi:10.1175/ JCLI-D-11-00616.1

Fatkhuroyan, F., Wati, T., Sukmana, A. \& Kurniawan, R. 2018 Validation of satellite daily rainfall estimates over Indonesia. Forum Geografi 32(2): 170-180. doi:10.23917/forgeo. v32i 2.6288

Funk, C., Peterson, P., Landsfeld, M., Pedreros, D., Verdin, J., Shukla, S., Husak, G., Rowland, J., Harrison, L., Hoell, A. \& Michaelsen, J. 2015. The climate hazards infrared precipitation with stations - A new environmental record for monitoring extremes. Scientific Data 2: 1-21. doi:10.1038/ sdata.2015.66

Huffman, G.J. \& Bolvin, D.T. 2015. Real-time TRMM multisatellite precipitation analysis data set documentation. NASA Tech. Doc. p. 10.

Jamaluddin, A.F., Tangang, F., Ibadullah, W.M.W., Juneng, L., Yik, D.J., Salimun, E., Dindang, A. \& Abdullah, M.H. 2019. Klimatologi kitaran hujan diurnal dan bayu laut-darat di Semenanjung Malaysia. Sains Malaysiana 48(3): 509-522. doi:10.17576/jsm-2019-4803-03

Jamaluddin, A.F., Tangang, F., Chung, J.X., Juneng, L., Sasaki, H. \& Takayabu, I. 2017. Investigating the mechanisms of diurnal rainfall variability over Peninsular Malaysia using the non-hydrostatic regional climate model. Meteorology and Atmospheric Physics 130: 1-23. doi:10.1007/s00703017-0541-x

Jamandre, C.A. \& Narisma, G.T. 2013. Spatio-temporal validation of satellite-based rainfall estimates in the Philippines. Atmospheric Research 122: 599-608. doi:10.1016/j. atmosres.2012.06.024

Jebson, S. 2007. National Meteorological Library and Archive 2007. Fact sheet No. 3 - Water in the atmosphere. http:// cedadocs.ceda.ac.uk/255/1/factsheet03.pdf

Joyce, R.J., Janowiak, J.E., Arkin, P.A. \& Xie, P. 2004. CMORPH: A method that produces global precipitation estimates from passive microwave and infrared data at high spatial and temporal resolution. Journal of Hydrometeorology 5(3): 487-503. doi:10.1175/1525-7541(2004)005

Kubota, T., Ushio, T., Shige, S., Kida, S., Kachi, M. \& Okamoto, K. 2009. Verification of high-resolution satellite-based rainfall estimates around Japan using a gauge-calibrated ground-radar dataset. Journal of the Meteorological Society of Japan 87(a): 203-222. doi:10.2151/jmsj.87a.203

Kummerow, C., Hong, Y., Olson, W.S., Yang, S., Adler, R.F., Mccollum, J., Ferraro, R., Petty, G., Shin, D.B. \& Wilheit, T.T. 2001. The evolution of the goddard profiling algorithm 
(GPROF) for rainfall estimation from passive microwave sensors. Journal of Applied Meteorology and Climatology 40(11): 1801-1820. doi:10.1175/1520-0450(2001)040

Lim J.T. 1979. Characteristics of the winter monsoon over the Malaysian region. PhD Thesis, University of Hawaii (Unpublished).

Mahmud, M.R., Hashim, M. \& Reba, M.N.M. 2017. How effective is the new generation of GPM satellite precipitation in characterizing the rainfall variability over Malaysia? AsiaPacific Journal of Atmospheric Sciences 53(3): 375-384. doi:10.1007/s13143-017-0042-3

Mohd, M.S.F., Juneng, L., Tangang, F., Rahman, N.F.A., Khalid, K. \& Haron, S.H. 2015. Simulation of upper Kuantan river basin streamflow using swat model. In AIP Conference Proceedings. Selangor, Malaysia. doi:10.1063/1.4931206

Pai, D.S., Sridhar, L., Guhathakurta, P. \& Hatwar, H.R. 2011. District-wide drought climatology of the southwest monsoon season over India based on standardized precipitation index (SPI). Natural Hazards 59(3): 1797-1813. doi:10.1007/ s11069-011-9867-8

Penang Kini 2017. Banjir Pulau Pinang Fenomena Fujiwhara Punca Banjir. https://www.penangkini.com/ search?updated-max=2017-11-08T03:38:00-08:00\&maxresults $=20 \&$ reverse-paginate $=$ true $\&$ start $=40 \&$ by-date $=$ false . Accessed on September 13, 2020.

Richard, S.S. 2010. The diurnal variations of rainfall and winds over Malaysia. Master Thesis, University of Hawaii (Unpublished).

Semire, F.A., Mohd-Mokhtar, R., Ismail, W., Mohamad, N. \& Mandeep, J.S. 2012. Ground validation of space-borne satellite rainfall products in Malaysia. Advances in Space Research 50(9): 1241-1249. doi:10.1016/j.asr.2012.06.031

Setiawati, M.D. \& Miura, F. 2016. Evaluation of GSMaP daily rainfall satellite data for flood monitoring: Case study Kyushu Japan. Journal of Geoscience and Environment Protection 4(12): 101-117. doi:10.4236/gep.2016.412008

Shige, S. \& Kummerow, C.D. 2016. Precipitation-top heights of heavy orographic rainfall in the asian monsoon region. Journal of the Atmospheric Sciences 73(8): 3009-3024. doi:10.1175/JAS-D-15-0271.1

Shige, S., Kida, S., Ashiwake, H., Kubota, T. \& Aonashi, K. 2013. Improvement of TMI rain retrievals in mountainous areas. Journal of Applied Meteorology and Climatology 52(1): 242-254. doi:10.1175/JAMC-D-12-074.1

Soo, E. Z.X., Wan Jaafar, W. Z., Lai, S. H., Othman, F., Elshafie, A., Islam, T., Srivastava, P. \& Othman Hadi, H.S. 2020. Evaluation of bias-adjusted satellite precipitation estimations for extreme flood events in Langat river basin, Malaysia. Hydrology Research 51(1): 105-126. doi:10.2166/ nh.2019.071

Soo, E.Z.X., Jaafar, W.Z.W., Lai, S.H., Islam, T. \& Srivastava, P. 2019. Evaluation of satellite precipitation products for extreme flood events: Case study in Peninsular Malaysia. Journal of Water and Climate Change 10(4): 871-892. doi:10.2166/wcc.2018.159
Svoboda, M., Hayes, M. \& Wood, D. 2012. Standardized Precipitation Index User Guide. Switzerland: World Meteorological Organization Geneva.

Tan, M.L., Tan, K.C., Chua, V.P. \& Chan, N.W. 2017. Evaluation of TRMM product for monitoring drought in the Kelantan River Basin, Malaysia. Water (Switzerland) 9(1). doi:10.3390/ w9010057

Tan, M.L., Ibrahim, A.L., Duan, Z., Cracknell, A.P. \& Chaplot, V. 2015. Evaluation of six high-resolution satellite and groundbased precipitation products over Malaysia. Remote Sensing 7(2): 1504-1528. doi:10.3390/rs70201504

Tangang, F., Farzanmanesh, R., Mirzaei, A., Supari, Salimun, E., Jamaluddin, A.F. \& Juneng, L. 2017. Characteristics of precipitation extremes in Malaysia associated with El Niño and La Niña events. International Journal of Climatology 37(S1): 696-716. doi:10.1002/joc.5032

Tangang, F.T., Juneng, L., Salimun, E., Vinayachandran, P.N., Seng, Y.K., Reason, C.J.C., Behera, S.K. \& Yasunari, T. 2008. On the roles of the northeast cold surge, the Borneo vortex, the Madden-Julian Oscillation, and the Indian Ocean dipole during the extreme 2006/2007 flood in Southern Peninsular Malaysia. Geophysical Research Letters 35(14): 1-6. doi:10.1029/2008GL033429

Trinh-Tuan, L., Matsumoto, J., Ngo-Duc, T., Nodzu, M.I. \& Inoue, T. 2019. Evaluation of satellite precipitation products over central Vietnam. Progress in Earth and Planetary Science 6: 54. doi:10.1186/s40645-019-0297-7

Wei, G., Lü, H., Crow, W.T., Zhu, Y., Wang, J. \& Su, J. 2018. Comprehensive evaluation of GPM-IMERG, CMORPH, and TMPA precipitation products with gauged rainfall over mainland China. Advances in Meteorology 2018: 3024190. doi: 10.1155/2018/3024190

Wong, C.L., Liew, J., Yusop, Z., Ismail, T., Venneker, R. \& Uhlenbrook, S. 2016. Rainfall characteristics and regionalization in Peninsular Malaysia based on a high resolution gridded data set. Water 8(11): 500-516. doi: $10.3390 / w 8110500$

Wong, C.L., Venneker, R., Jamil, A.B.M. \& Uhlenbrook, S. 2011. Development of a gridded daily hydrometeorological data set for Peninsular Malaysia. Hydrological Processes 25(7): 1009-1020. doi:10.1002/hyp.7654

Wu, H., Adler, R.F., Tian, Y., Huffman, G.J., Li, H. \& Wang, J. 2014. Real-time global flood estimation using satellitebased precipitation and a coupled land surface and routing model. Water Resources Research 50(3): 2693-2717. doi:10.1002/2013WR014710

Xie, P., Joyce, R., Wu, S., Yoo, S.H., Yarosh, Y., Sun, F. \& Lin, R. 2017. Reprocessed, bias-corrected CMORPH global high-resolution precipitation estimates from 1998. Journal of Hydrometeorology 18(6): 1617-1641. doi:10.1175/ JHM-D-16-0168.1

Yik, D.J., Sang, Y.W., Chang, N.K., Fakaruddin, F.J., Dindang, A. \& Abdullah, M.H. 2018. Analysis of the cyclonic vortex and evaluation of the performance of the radar integrated nowcasting system (RaINS) during the heavy rainfall episode 
which caused flooding in Penang, Malaysia on 5 november 2017. Tropical Cyclone Research and Review 7(4): 217-229. doi:10.6057/2018TCRR04.03

Zin, W.Z.W., Jemain, A.A. \& Ibrahim, K. 2013. Analysis of drought condition and risk in Peninsular Malaysia using Standardised Precipitation Index. Theoretical and Applied Climatology 111(3-4): 559-568. doi:10.1007/s00704-0120682-2
Malaysian Meteorological Department

Jalan Sultan

46667 Petaling Jaya, Selangor Darul Ehsan

Malaysia

*Corresponding author; email: fairudz@met.gov.my

Received: 21 December 2020

Accepted: 21 May 2021 